\title{
A Real Options Approach to Distressed Property Borrower-Lender Reconciliation
}

\author{
David J. Moore*, Nuriddin Ikromov \\ College of Business Administration, California State University, Sacramento, CA, USA \\ Email: ${ }^{*}$ djmphd@csus.edu
}

Received 5 February 2015; accepted 23 February 2015; published 25 February 2015

Copyright (C) 2015 by authors and Scientific Research Publishing Inc.

This work is licensed under the Creative Commons Attribution International License (CC BY). http://creativecommons.org/licenses/by/4.0/

(c) (i) Open Access

\begin{abstract}
We propose a real option framework to value distressed properties and restructure their loans. Our approach reconciles the interests of borrowers and lenders through a constrained optimization model yielding mutually beneficial restructure terms. Borrowers receive lower loan balances and payments, while lenders replace non-performing loans with performing loans that have higher market values. A numerical illustration shows that the market value of a restructured loan can exceed that of the original non-performing loan and the post-foreclosure cash flows when the lender repossesses the property.
\end{abstract}

\section{Keywords}

Real Option, Real Estate, Restructure, Distressed Property, Market Value

\section{Introduction}

Many studies have applied option theory to real estate investment, abandonment, and timing decisions over the past three decades. [1] is one of the first studies to applying real options theory to real estate development and to offer a theoretical model of valuation of vacant lots. [2] offers an analytical and numerical solution for the option to develop or abandon real estate. [3]-[5] derive models of pricing lease contracts in the option pricing context. [6] applies real option theory to value adjustable-rate mortgages in the presence of default, and [7] surveys the theoretical studies on the option pricing methodology of mortgage valuation. [8] applies option theory to explain the cyclical nature of real estate markets. [9] finds that individual investors are unable to apply real options theory to investment decisions in a laboratory experiment. However, prior real estate applications of option theory are from the perspective of developers or financial institutions. To our knowledge, this study is the first to apply option theory to real estate from a household perspective. This study extracts home values from the option

${ }^{*}$ Corresponding author. 
pricing framework. We then use the estimated market value in a constrained maximization problem to produce mutually beneficial loan restructure terms.

Figure 1 illustrates that the market-to-book ratio for non-performing loans is consistently lower than that of performing loans from 1990 to 2013. Overall, the average market-to-book value of non-performing loans (35\%) is less than half of performing loans (83\%). We investigate whether or not a non-performing loan can be restructured into a performing loan, if the restructured loan (likely with a lower balance) has a higher market value than the original non-performing loan, and if the new loan terms are in the best interest of the borrower and lender.

The precipitous drop in home loan market values coupled with increased reserve requirements has necessitated loan restructuring. However lenders are often unwilling to restructure loans. We suggest one reason lenders are apprehensive is that they are unaware of the related issues of current home valuation and optimum restructuring terms. [10] refers to this scenario as "a lender's dilemma." Our study proposes a constrained optimization model that provides optimal loan restructuring terms and distressed property valuation. We obtain these results by observing that borrowers have a real option and incorporating the value of that option in the lender's maximization problem.

To illustrate the potential benefits to borrowers and lenders, consider the average market-to-book values for performing and non-performing loans, $83 \%$ and $35 \%$, respectively. The restructured loan market value will exceed the non-performing loan market value as long as the restructured principal balance is greater than $0.35 / 0.83 \approx 42 \%$ of the original principal balance. For example, assume anon-performing loan balance of $\$ 100,000$. Further assume that a reduction of principal balance to $\$ 70,000$ produces a performing loan. The market values before and after restructuring are:

$$
\begin{aligned}
& \mathrm{MV}_{\text {before }}=\mathrm{MV}_{\text {nonperf }}=0.35(100,000)=35,000 ; \\
& \mathrm{MV}_{\text {after }}=\mathrm{MV}_{\text {restructured }}=0.83(70,000)=58,100
\end{aligned}
$$

The lender can increase the market value of the non-performing loans $66 \%$ by restructuring into performing loans. Of course there are many other choice variables for the lender such as the loan rate and term. The trio of principal reduction percentage, loan rate, and loan term are used as the lender's choice variables in our model that follows.

\section{Model}

For the purposes of this study, a "distressed" property is a property where a homeowner has ceased repayment due an "underwater" condition: the current loan balance exceeds the current market value of the home. Our

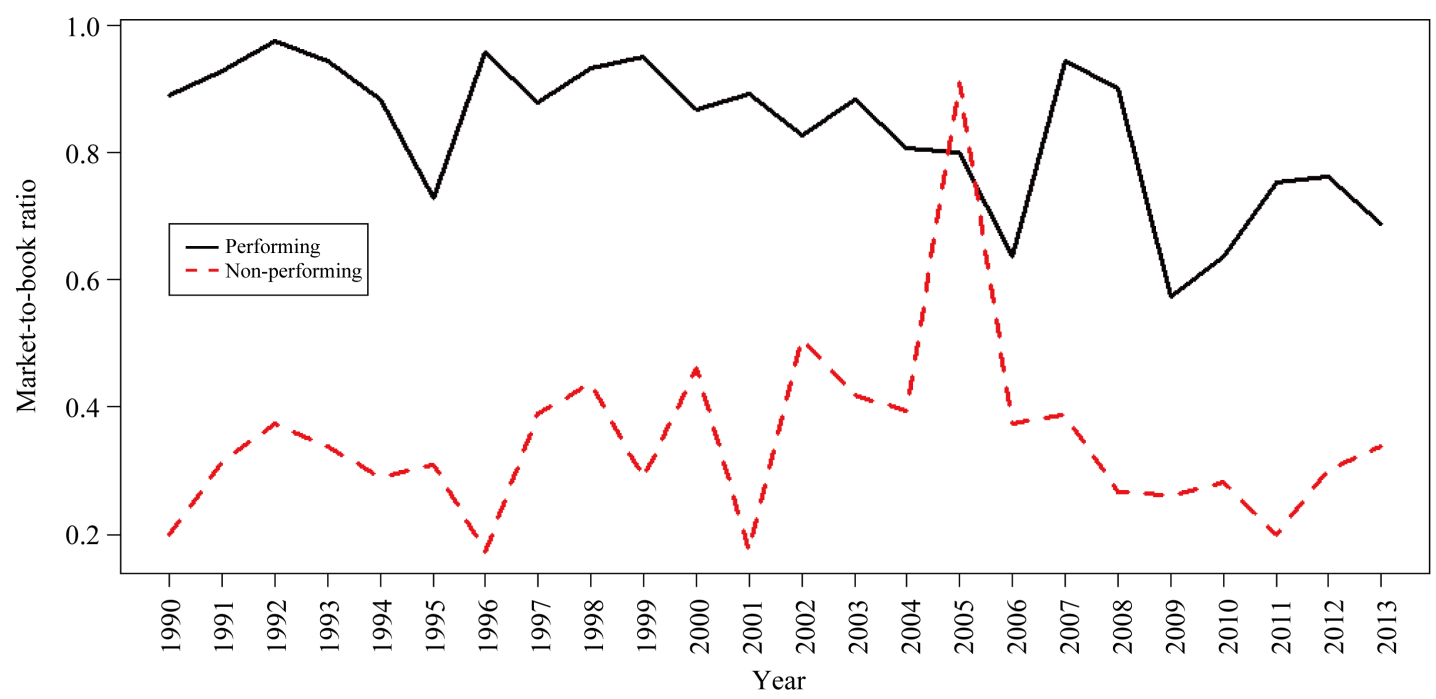

Figure 1. Average market-to-book ratio for performing and nonperforming loans from 1990 to 2013. Source: FDIC historical loan sales data (http://www.fdic.gov/buying/historical/index.html). 
model first implementsthe underwater condition by setting the real option value to the borrower to zero, and then solving for the current market value of the home $S_{0}$ ("stock price" in standard options nomenclature). Given the current distressed property market value $S_{0}$ and existing loan amount $K_{0}$, the lender chooses the principal reduction amount $a$, new interest rate $r$, and new loan term $T$ that maximizes the value of the now-performing loan $b_{p} a K_{0}$ subject to several constraints. The constraints are defined to ensure the real option to the homeowner is positive (the performing condition), the market value of the restructured performing loan exceeds that of the existing non-performing loan, and the loan terms are within reasonable market conditions. We begin by describing the assumptions and constraints in detail then follow with the model specification.

\subsection{Assumptions}

We make several simplifying assumptions for model tractability. These assumptions are intentionally restrictive in that we do not intend for this model to apply to all non-performing loans. However, loans that meet the criteria identified in the following assumptions do represent a subset of all non-performing loans.

Assumption 1: The non-performing loan represents a negative equity scenario where the real option value on the home is equal to zero. Admittedly, it is possible that a loan is non-performing for reasons other than negative equity. The borrower may have experienced unemployment or under-employment recently or an investor may walk away from a property in which mortgage payments exceed rental income. In either case, borrowers and investors can avoid default by selling unless the home has negative equity. Hence, this study focuses on negative equity distressed properties.

Assumption 2: The loan will become performing after restructuring. The restructured loan, by construction of our model, has a lower balance, lower monthly payments, and a positive real option value. Assuredly, not all home loans can be restructured. However, we consider successful convergence to a solution, subject to several constraints, an indication of potential applicability. We deem the loan a restructure candidate when the model converges to a solution. We do not consider the loan a restructure candidate when the model does not converge.

Assumption 3: The home price process follows a lognormal distribution. We make this assumption to apply the Black-Scholes pricing valuation to our model. This is a standard assumption with option pricing made in [11], and implemented in [12] and [13].

Assumption 4: The The borrower's time horizon is $t$ years. We acknowledge that the same agreement was made in the non-performing original loan. However, since the output of our model is a restructured loan beneficial to both the borrower and the lender, we consider $t$, which is distinct from the loan term $T$, a required commitment from the borrower for restructuring to occur.

Additional simplifying assumptions.We further assume the market-to-book-value of non-performing loans and performing loans remains constant. In line with option pricing practice, we also assume that price volatility and the risk free rate are stationary, there are no transaction costs or taxes, and the stock (home) does not pay a dividend. It is true that these assumptions do not always hold in the real world. However, the transaction costs and taxes will be minimal for a distressed property due to a major decline in value. In addition, although rental revenue may be positive, it is likely offset by costs of maintaining the property. Finally, [1] describes, if real estate investments of publicly-traded firms "are chosen in a manner consistent with value maximization, then real estate prices will be determined in equilibrium as if markets were really frictionless.”

\subsection{Current Home Value Based on Real Option Value under Distress}

The current valueof the distressed property $S_{0}$ is obtained by setting value of the distressed home real option $c_{\text {dis }}$ equal to zero:

$$
\begin{aligned}
& c_{\mathrm{dis}}=S_{0} N\left[d_{\mathrm{dis}, 1}\right]-K_{\mathrm{dis}, t} \mathrm{e}^{-r_{f} t} N\left[d_{\mathrm{dis}, 2}\right]=0 \\
& d_{\mathrm{dis}, 1}=\frac{\ln \left[S_{0} / K_{\mathrm{dis}, t}\right]+\left(r_{f}+\frac{\sigma^{2}}{2}\right) t}{\sigma \sqrt{t}} \\
& d_{\mathrm{dis}, 2}=d_{\mathrm{dis}, 1}-\sigma \sqrt{t}
\end{aligned}
$$

where $K_{\mathrm{dis}, t}$ is future value of the distressed loan if the borrower continued making payments. $K_{\mathrm{dis}, t}$ is com- 
puted as

$$
K_{\mathrm{dis}, t}=K_{0} \frac{1-\mathrm{e}^{-r_{\mathrm{dis}}(T-t)}}{1-\mathrm{e}^{-r_{\mathrm{dis}} T}}
$$

where $r_{\text {dis }}$ is the current interest rate on the distressed loan. We use numerical methods to solve Equation (1) for $S_{0}$.

\subsection{Real Option Value under Restructuring}

The real option value of the restructured loan to the borrower is computed in the same fashion as under distress with changes to the interest rate $r_{\text {dis }}$ and strike price $K_{\text {res }}$ using the Black-Scholes option pricing model:

$$
\begin{aligned}
& c_{\text {res }}=S_{0} N\left[d_{\text {res }, 1}\right]-K_{\text {res }, t} \mathrm{e}^{-r_{f} t} N\left[d_{\text {res }, 2}\right] \\
& d_{\text {res }, 1}=\frac{\ln \left[S_{0} / K_{\text {res }, t}\right]+\left(r_{f}+\frac{\sigma^{2}}{2}\right) t}{\sigma \sqrt{t}} \\
& d_{\text {res }, 2}=d_{\text {res }, 1}-\sigma \sqrt{t}
\end{aligned}
$$

where $S_{0}$ is the current market value of the distressed property, $t$ represents the time commitment of the borrower (see Assumption 4), and $K_{\text {res, } t}$ is the principal balance at time $t$ represented by:

$$
K_{\text {res, }}=\left((1-a) K_{0}\right) \frac{1-\mathrm{e}^{-r(T-t)}}{1-\mathrm{e}^{-r T}}
$$

\subsection{Real Option Value under Foreclosure}

Should the lender reposses the home and sell on the open market (referred to Real Estate Owned or REO sale), the foreclosed home will sell at a discount to its current market value. This discount can be attributed to expected repairs associated with a property that has been vacant for six months or more (RealtyTrac). In a REO sale both the lender and third party buyer incur repair expenses [14]. Let $z$ be the prevailing market discount of REO sales such that the amount paid for the foreclosed home by a third party is $S_{\text {for }, 0}=(1-z) S_{0}, E_{b}$ be the repair expense for the buyer, $E_{l}$ be the repair expense for the lender, $\gamma$ be the down payment requirement dictated by current market conditions, and $r_{\text {mkt }}$ be the current market rate for 30 year home loans. The real option value to the third party purchaser of this REO home is computed as:

$$
\begin{aligned}
& c_{\text {for }}=S_{\text {for }, 0} N\left[d_{\text {for }, 1}\right]-K_{\text {for }, t} \mathrm{e}^{-r_{f} t} N\left[d_{\text {for }, 2}\right] \\
& d_{\text {for }, 1}=\frac{\ln \left[S_{0} / K_{\text {for }, t}\right]+\left(r_{f}+\frac{\sigma^{2}}{2}\right) t}{\sigma \sqrt{t}} \\
& d_{\text {for }, 2}=d_{\text {for }, 1}-\sigma \sqrt{t}
\end{aligned}
$$

where

$$
K_{\text {for }, t}=(1-\gamma)\left(S_{\text {for }, 0}+E_{b}\right) \frac{1-\mathrm{e}^{-r_{\text {mkt }}(T-t)}}{1-\mathrm{e}^{-r_{\text {mkt }} T}}
$$

Note that the cash flow to the lender in the REO sale is not the sale price $S_{\text {for }, 0}$, rather, the sale price less any repair expenses incurred to make the home available for sale $S_{\text {for }, 0}-E_{l}$.

\subsection{Constrained Optimization Model}

The lender chooses the loan balance discount $a$, the new loan interest rate $r$, and the new loan term $T$ to maximize the current value of the newly-formed performing loan subject to several constraints. 


$$
\max _{a, r, T} b_{p}\left((1-a) K_{0}\right) \text { subject to }\left\{\begin{array}{l}
0<a<1 \\
c_{\text {res }}=0.5 c_{\text {for }} \\
b_{p}\left((1-a) K_{0}\right)>b_{n p} K_{0} \\
r \geq r_{\text {mkt }} \\
T_{\text {orig }}<T \leq 30
\end{array}\right.
$$

where $b_{p}$ is the proportion of performing loan balance that translates into market value, $b_{n p}$ is the proportion of the non-performing loan balance that translates into market value, $K_{0}$ is the original non-performing loan balance, $(1-a) K_{0}$ represents the restructured loan balance, $c_{\text {res }}$ is the value of the real option on the home if under restructuring, $c_{\text {for }}$ is the value of the real option on the home if it were purchased from the lender after foreclosure, and $r_{\mathrm{mkt}}$ is the average market rate for 30 year conforming loans. Note that the monthly mortgage payment of the new performing loan $\mathrm{PMT}_{p}$ is less than the monthly payment of the old non-performing loan $\mathrm{PMT}_{n p}$ by construction. The endogenous variables are the lender's choice variables $(a, r, T)$, i.e., the new loan terms. The exogenous variables are the current home price $S_{0}$, the market rate $r_{\text {mkt }}$, volatility $\sigma$, time commitment to remain in the home $t$, and loan market-to book value ratios $b_{p}$ and $b_{n p}$. We now briefly discuss each constraint.

Constraint C1: The restructured loan must be smaller than the original loan. This constraint follows Assumption 1 and the suggestion by [15] to reduce loan balances and split potential gains (Constraint C2) to fix the US mortgage crisis. In addition, this constraint focuses our model on negative equity non-performing loans and ensures a lower monthly payment. The combination of lower loan balance and lower monthly payments follows Assumption 2: the loan will become performing after restructuring.

Constraint C2: The borrower and lender evenly split potential gains. This constraint guides our model to a solution that is mutually beneficial to borrowers and lenders. Simply reducing a principal balance just to bring a borrower current may be insufficient incentive for a lender. We incorporate the suggestion of shared gains [15] via this constraint.

Constraint C3: The market value of the restructured performing loan must exceed the market value of the current non-performing loan. This constraint is included to ensure that restructuring is beneficial to the lender. Without this constraint it would be possible to restructure into a performing loan whose market value is lower than the current non-performing loan.

Constraint C4: The new loan rate must be greater than or equal to the market rate for performing loans.A lender may be unable to fund loans at rates below the current market rate. Therefore, we require the restructured rate tobe at least the average market rate for performing 30 year loans.

Constraint C5: The new loan term is between the current loan term and 30 years. Given the finite lives of borrowers and customary industry practice we restrict the maximum new loan term to 30 years. Also, setting the minimum term to the remaining term on the existing loan follows Assumption 2 (the loan will become performing due to lower balance and payment).

Again, we utilize numerical optimization methods to solve the constrained optimization problem in Equation (13) to produce optimum values of the lender choice variables $\left(a^{*}, r^{*}, T^{*}\right)$.

\section{Numerical Illustration}

\subsection{Data and Parameterization}

We obtain the average market rate for 30 year conforming loans $r_{\text {mkt }}$ from the 2014 Freddie Mac Primary Mortgage Market Survey ${ }^{\circledR}$ (PMMS) and the 30 year risk free rate $r_{f}$ from the United States Treasury. We use the Federal Housing Finance Agency (FHFA) US Housing Price Index (HPI) to obtain the annual US home price volatility $\sigma$. The Federal Deposit Insurance Corporation (FDIC) home loan sales data is our source for the market-to-book ratios of non-performing $b_{n p}$ and performing $b_{p}$ loans. Our average length of home ownership $t$, average down payment requirement $\gamma$, and average Real Estate Owned (REO) discount $z$ values are from the National Association of Realtors, mortgageqna.com, and RealtyTrac.com, respectively. Finally, average REO repair expense for the buyer $E_{b}$ and the lender $E_{l}$ are from [14].

Table 1 summarizes the exogenous variables, values, and sources used in this study. Figure 2 depicts the FHFA US home price index level data. The rapid growth in housing prices from 1997 to the 2006 peak, the 
Table 1. Parameters, values, and sources.

\begin{tabular}{cccc}
\hline Symbol & Description & Value & Source \\
\hline$r_{\mathrm{mkt}}$ & US average market rate of 30 year conforming loan & $4.20 \%$ & Freddie Mac PMMS, September 2014 \\
$r_{f}$ & Risk free rate. & $3.21 \%$ & US Treasury, September 2014 \\
$\sigma$ & Annual US home price volatility & $4.77 \%$ & FHFA HPI 1991Q1 to 2014Q3 \\
$b_{n p}$ & Non-performing loan market to book ratio & 0.3379 & FDIC 2014Q3 home loan sales data \\
$b_{p}$ & Performing loan market to book ratio & 0.6877 & FDIC 2014Q3 home loan sales data \\
$t$ & Average length of home ownership & 6 years & National Association of Realtors \\
$\gamma$ & Average down payment requirement & $10 \%$ & mortgageqna.com \\
$Z$ & Average REO discount from market value & $35.90 \%$ & RealtyTrac \\
$E_{b}$ & Average buyer REO repair expense & 7663 & La Jeunesse [14] \\
$E_{l}$ & Average lender REO repair expense & 2252 & La Jeunesse [14] \\
\hline
\end{tabular}

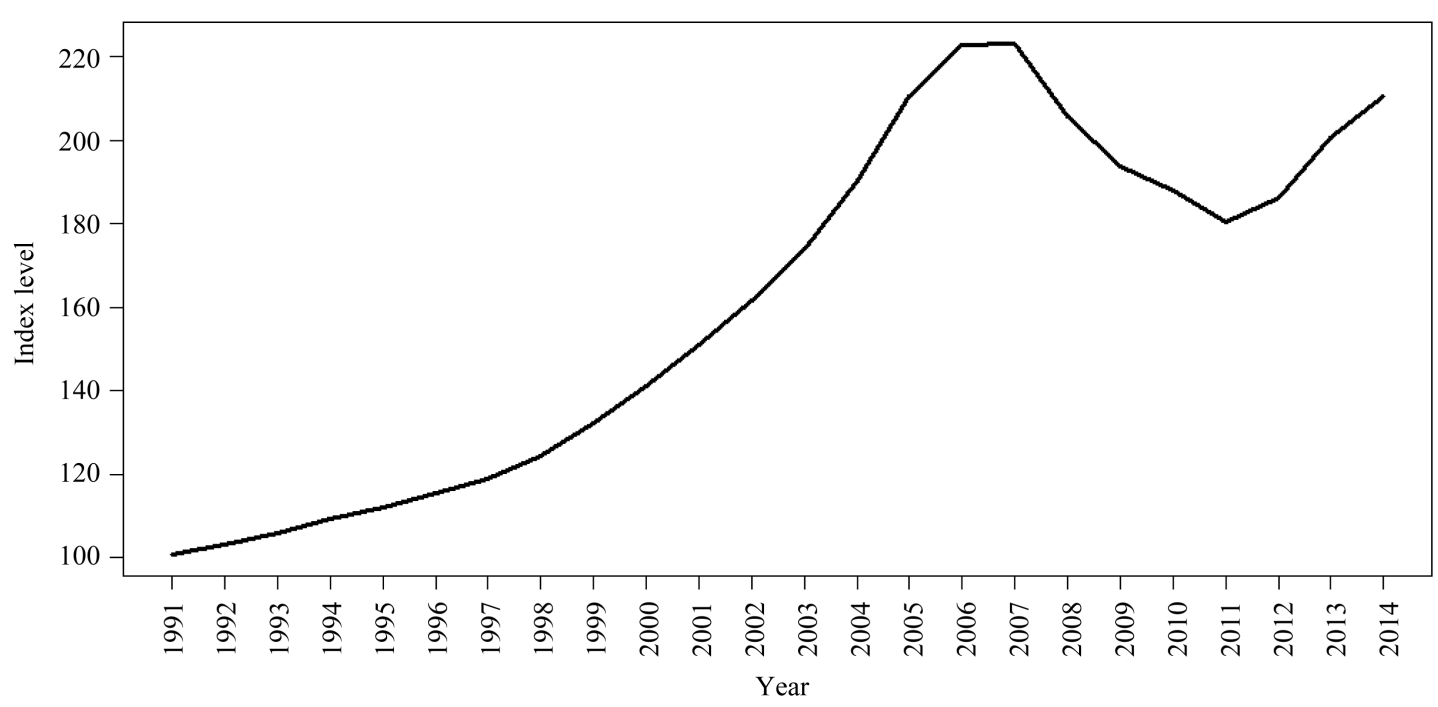

Figure 2. US housing price index level from 1991Q1 to 2014Q3. Source: Federal Housing Finance Agency.

correction from 2006 to mid-2011, and the post-2011 rebound are evident. Figure 3 depicts the returns calculated from the FHFA US home price index level data. Returns averaged 3.36\% with a standard deviation of $\sigma=4.77 \%$ during 1991Q1 to 2014Q3 time period.

\subsection{Distressed Property Valuation}

We begin our illustration with the median values of negative equity loans from [16]. Specifically, we establish our base case by setting the currently non-performing loan balance to the median mortgage balance at termination (default) $K_{\mathrm{dis}, 0}=\$ 359,000$, the original interest rate to the median rate at origination $r_{\mathrm{dis}}=7.5 \%$, and the original loan term to the median time remaining at termination $T_{\text {dis }}=28.5$. Given the parameterization of Table 1 and the median characteristics of non-performing loans from [16], our model in Equation (12) produces an estimate of the current value of the distressed property $S_{0}=\$ 189,427$.

Next, we perform a sensitivity analysis to investigate factors that impact distressed property values. The results of the sensitivity analysis are presented in Figure 4. Several observations are of note. First, home valuesare most sensitive to the current non-performing loan balance $K_{\text {dis }}$. This result reveals that even though the intial home purchase may have been at an inflated price, the associated loan balance still reflects information about the fundamental home value. Second, homes with more mature negative equity loans (lower $T_{\text {dis }}$ ) are of 


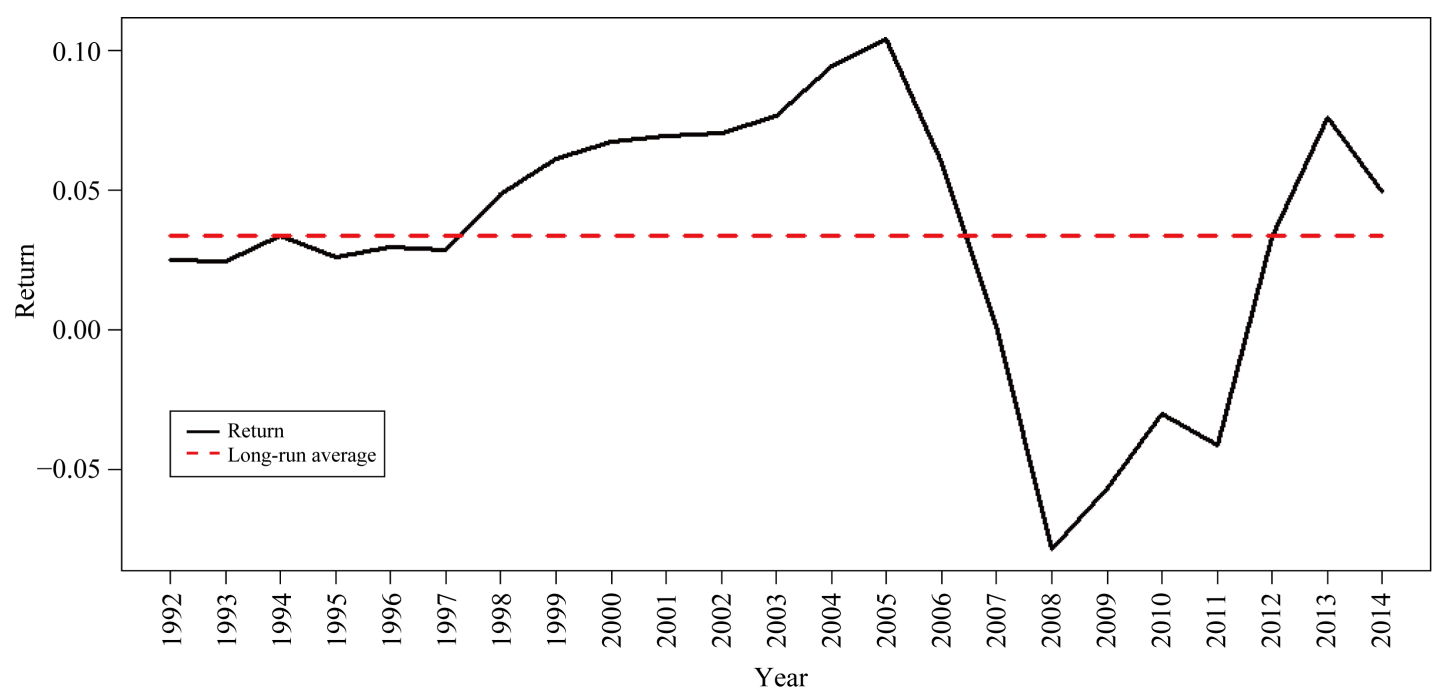

Figure 3. US housing price index returns from 1991Q1 to 2014Q3. Source: Federal Housing Finance Agency.

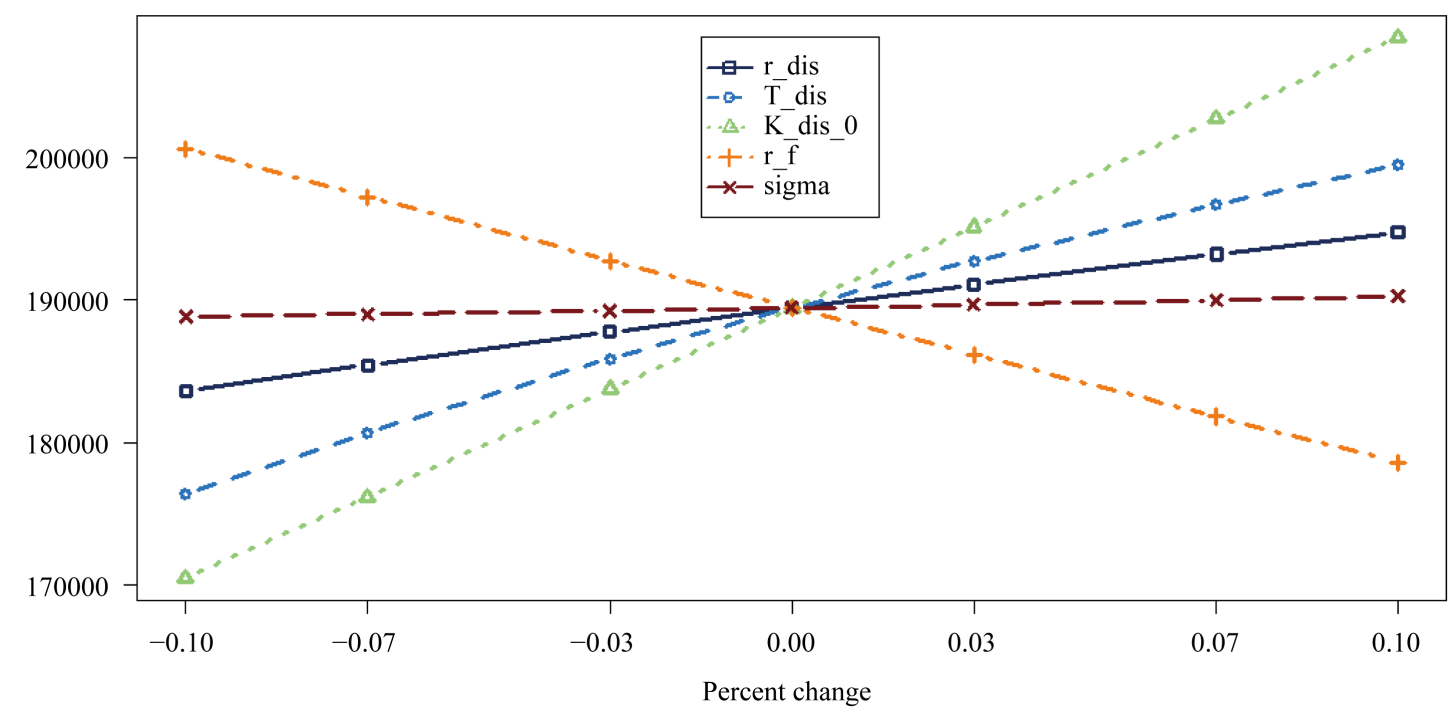

Figure 4. Home value sensitivity to changes in model inputs.

lower value. This could reveal that additional years of payments were unable to bring the loan balance of an extremely inflatedpurchase price in line with the fundamental value. Third, home values are relatively insensitive to the original interest rate $r_{\text {dis }}$. This result is not surprising given the median time from purchase to default is 18 months [16]. Fourth, home valuesare relatively insensitive to volatility. This result suggests inflated purchase prices drive the negative equity position rather than volatility. Finally, home value declines as the risk free rate increases. This result is consistent with the known inverse relationship between interest rates and housing prices.

\subsection{Borrower-Lender Reconciliation}

We determine optimum loan restructuring terms for the base case using our real options-based distressed property value estimate. We employ numerical methods [17] to solve the constrained nonlinear optimization model of Equation (13). The optimized loan reduction amount, loan rate, and loan term are $a^{*}=47.10 \%, r^{*}=4.20 \%$ and $T^{*}=28.5$, respectively. The resultant performing loan market value of $\$ 130,599$ represents a $9.59 \%$ improvement over the status quo non-performing loan market value of $\$ 119,171$. Figure 5 shows the value of a restructured loan $V_{\text {res }}=b_{p}\left((1-a) K_{0}\right)$ is larger than both the non-performing loan $V_{\text {dis }}=b_{n p} K_{0}$ and the value 
to the lender post foreclosure sale $V_{\text {for }}=(1-z) S_{0}-E_{l}$. Interestingly, the lender is better off selling the nonperforming loan for $\$ 121,306$ than foreclosing on the home to receive $\$ 119,171$.

We now examine optimality conditions for different non-performing loan balances. Table 2 details the impact of initial loan balance $K_{0}$ on optimality conditions $\left(a^{*}, r^{*}, T^{*}\right)$, option value to borrower $c_{\text {res }}$, option value to third-party purchaser at foreclosure $c_{\text {for }}$, value to the lender if non-performing loan is sold $V_{\text {dis }}$, value to the lender if they chose to foreclose $V_{\text {for }}$, and finally the value to the lender if they chose to restructure $V_{\text {res }}$. The lender realizes more value via restructuring for all non-performing loan balances shown. However, the benefit to the lender decreases as the non-performing loan balance increases. Restructuring a relatively small non-performing loan balance of $\$ 251,300$ results in a $25.44 \%$ improvement over foreclosure. In contrast, the improvement over foreclosure is just $1.29 \%$ when restructuring the relatively larger non-performing loan balance of $\$ 466,700$.

\subsection{Analysis of Results}

The restructured value $V_{\text {res }}$ exceeds the foreclosure value $V_{\text {for }}$ for all initial non-performing loan balances examined. Restructuring benefits borrowers since they retain their residence, become current on their mortgage, mitigate negative credit impacts, and minimize legal fees. We do not include transaction costs to the lender. However, inclusion of the lender costs associated with REO sales (legal fees, real estate commissions, etc.) would only increase the attractiveness of restructuring over foreclosure. In addition, our results show that lenders are better off selling non-performing loans than proceeding through foreclosure $\left(V_{\text {dis }}>V_{\text {for }}\right)$. Finally, we find it particularly interesting that the benefit to lenders diminishes as the home value increases. These findings can serve as guidance to lenders as they wrestle with non-performing loans now and into the future.

\section{Conclusion}

We present a method to establish the market value of distressed properties and a model to reconcile the interests

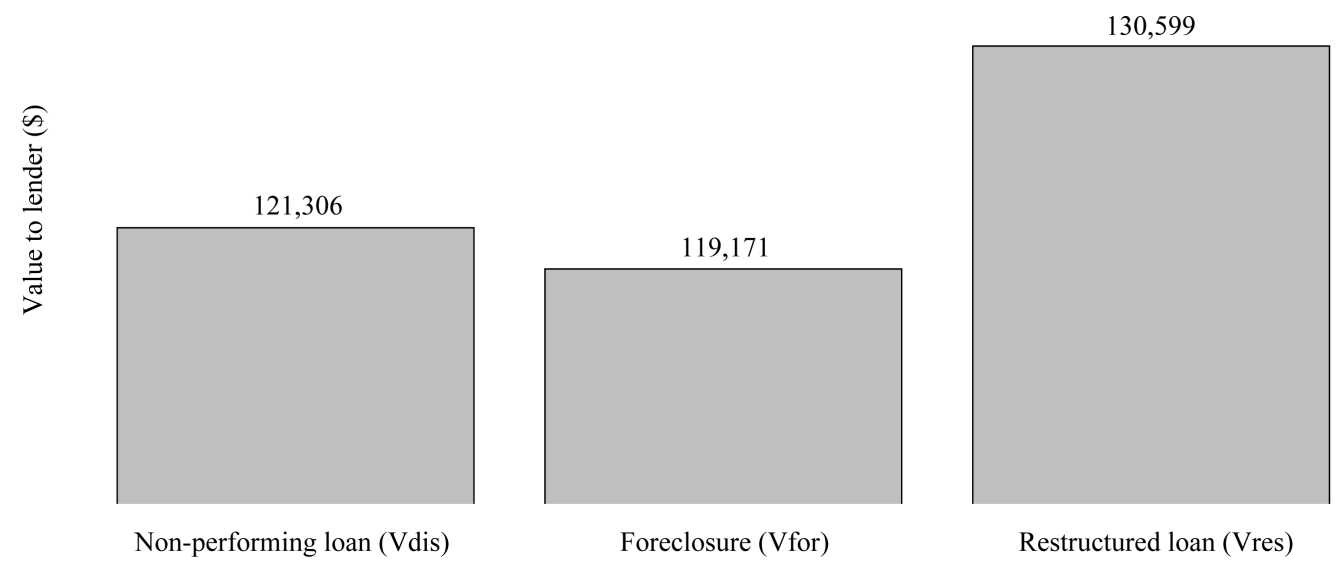

Figure 5. Value to lender under base case.

Table 2. Model outputs.

\begin{tabular}{cccccccccc}
\hline$K_{0}$ & $S_{0}$ & $a^{*}$ & $r^{*}$ & $T^{*}$ & $c_{\text {res }}$ & $c_{\text {for }}$ & $V_{\text {dis }}$ & $V_{\text {for }}$ & $V_{\text {res }}$ \\
\hline 251,300 & 132,599 & 0.3994 & 0.0420 & 28.5 & 23,825 & 47,649 & 84,914 & 82,744 & 103,797 \\
287,200 & 151,542 & 0.4297 & 0.0420 & 28.5 & 33,296 & 66,592 & 97,045 & 94,886 & 112,644 \\
323,100 & 170,485 & 0.4527 & 0.0420 & 28.5 & 42,767 & 85,535 & 109,175 & 107,029 & 121,604 \\
359,000 & 189,427 & 0.4710 & 0.0420 & 28.5 & 52,239 & 104,477 & 121,306 & 119,171 & 130,599 \\
394,900 & 208,370 & 0.4859 & 0.0420 & 28.5 & 61,710 & 123,420 & 133,437 & 131,313 & 139,606 \\
430,800 & 227,313 & 0.4984 & 0.0420 & 28.5 & 71,181 & 142,363 & 145,567 & 143,455 & 148,617 \\
466,700 & 246,255 & 0.5089 & 0.0420 & 28.6 & 80,563 & 161,306 & 157,698 & 155,598 & 157,608 \\
\hline
\end{tabular}


of borrowers and lenders. Our approach applies real option theory using the Black-Scholes option pricing formula, a constrained maximization framework, and numerical methods. Sensitivity analysis reveals distressed property values are most sensitive to the non-performing loan balance and least sensitive to market volatility. The non-performing loan balance sensitivity indicates information remains in the non-performing balance. The volatility insensitivity suggests the resulting negative equity position of distressed homes is driven more by inflated purchase prices than overall market volatility. We present evidence that restructuring is the highest value alternative among the lender's choice to sell the loan, foreclose, or restructure. Borrowers also benefit from principal and interest rate reductions. We show that the real option under restructuring is a significant improvement over the zero-value option during non-performance. Overall, we believe our approach can be used to arrive at mutually beneficial loan terms thereby relieving current and future negative equity positions.

\section{References}

[1] Titman, S. (1985) Urban Land Prices under Uncertainty. The American Economic Review, 75, 505-514.

[2] Williams, J.T. (1991) Real Estate Development as an Option. The Journal of Real Estate Finance and Economics, 4, 191-208. http://dx.doi.org/10.1007/BF00173124

[3] McConnell, J.J. and Schallheim, J.S. (1983) Valuation of Asset Leasing Contracts. Journal of Financial Economics, 12, 237-261. http://dx.doi.org/10.1016/0304-405X(83)90037-5

[4] Grenadier, S.R. (1995) Valuing Lease Contracts a Real-Options Approach. Journal of Financial Economics, 38, 297331. http://dx.doi.org/10.1016/0304-405X(83)90037-5

[5] Grenadier, S.R. (1996) Leasing and Credit Risk. Journal of Financial Economics, 42, 333-364. http://dx.doi.org/10.1016/0304-405X(83)90037-5

[6] Kau, J.B., Keenan, D.C., Muller III, W.J. and Epperson, J.F. (1993) Option Theory and Floating-Rate Securities with a Comparison of Adjustable-and Fixed-Rate Mortgages. Journal of Business, 66, 595-618. http://dx.doi.org/10.1086/296619

[7] Kau, J.B. and Keenan, D.C. (1995) An Overview of the Option-Theoretic Pricing of Mortgages. Journal of Housing Research, 6, 217-244.

[8] Grenadier, S.R. (1995a) The Persistence of Real Estate Cycles. The Journal of Real Estate Finance and Economics, 10, 95-119. http://dx.doi.org/10.1007/BF01096984

[9] Yavas, A. and Sirmans, C.F. (2005) Real Options: Experimental Evidence. The Journal of Real Estate Finance and Economics, 31, 27-52. http://dx.doi.org/10.1007/s11146-005-0992-6

[10] Berger, J.A., Sullivan, M.P. and Sood, S.S. (2009) Restructuring Non-Performing Commercial Real Estate Loans: A Lender's Dilemma. Real Estate Finance Journal, 25, 5.

[11] Hull, J.C. (2006) Options, Futures, and Other Derivatives. Sixth Edition, Prentice-Hall, Englewood Cliff.

[12] Benninga, S. and Wiener, Z. (1997) The Binomial Option Pricing Model. Mathematica in Education and Research, 6, 27-34.

[13] Benninga, S. and Wiener, Z. (1997) Binomial Option Pricing, the Black-Scholes Option Pricing Formula, and Exotic Options. Mathematica in Education and research, 6, 11-14.

[14] La Jeunesse, E. (2013) Home Improvement Spending on Distressed Properties: 2011 Estimates. Joint Center for Housing Studies, Harvard University, N13-1.

[15] Wheaton, W. (2010) A Fair and Easy Way to Fix the US Mortgage Crisis. Business Insider. http://www.businessinsider.com/a-fair-and-easy-way-to-fix-the-us-mortgage-crisis-2010-9

[16] Bhutta, N., Dokko, J. and Shan, H. (2010) The Depth of Negative Equity and Mortgage Default Decisions. Division of Research \& Statistics and Monetary Affairs, Federal Reserve Board.

[17] Powell, M.J. (1994) A Direct Search Optimization Method That Models the Objective and Constraint Functions by Linear Interpolation. In: Gomez, S. and Hennart, J.-P., Eds., Advances in Optimization and Numerical Analysis: Mathematics and Its Applications, Springer Netherlands, 51-67. http://dx.doi.org/10.1007/978-94-015-8330-5_4 
Scientific Research Publishing (SCIRP) is one of the largest Open Access journal publishers. It is currently publishing more than 200 open access, online, peer-reviewed journals covering a wide range of academic disciplines. SCIRP serves the worldwide academic communities and contributes to the progress and application of science with its publication.

Other selected journals from SCIRP are listed as below. Submit your manuscript to us via either submit@scirp.org or Online Submission Portal.
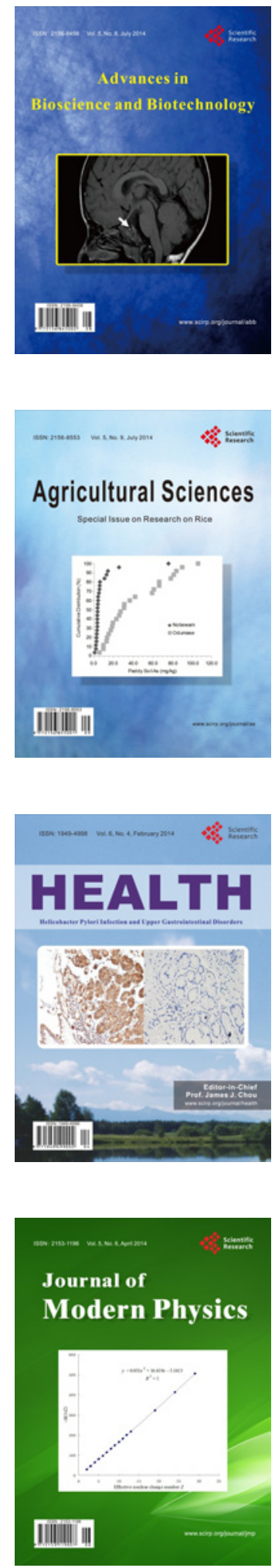
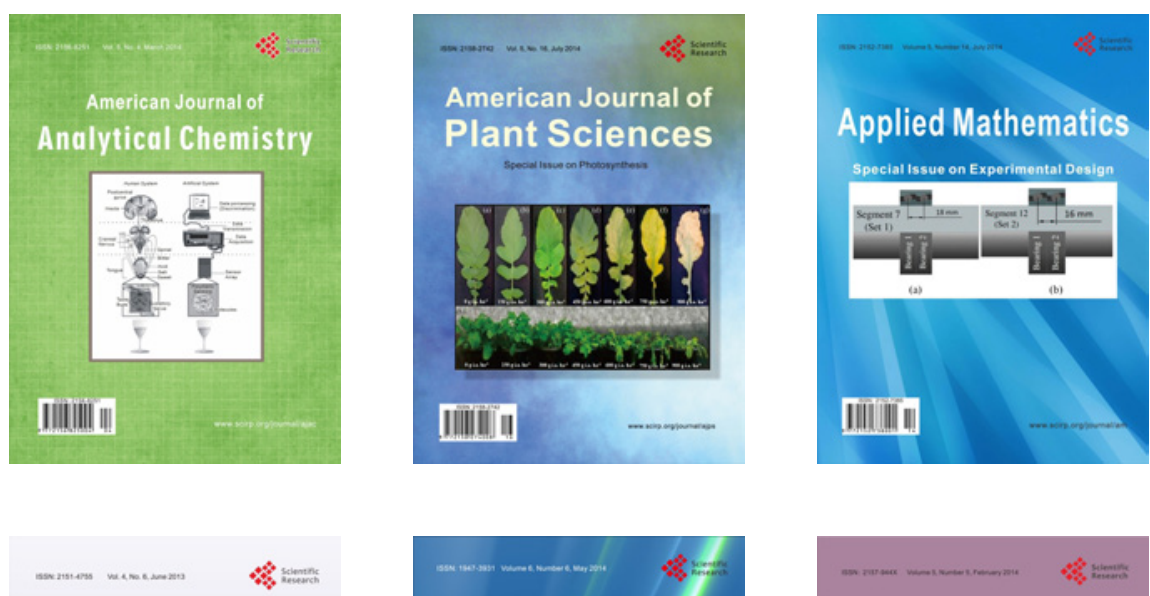

Creative Education
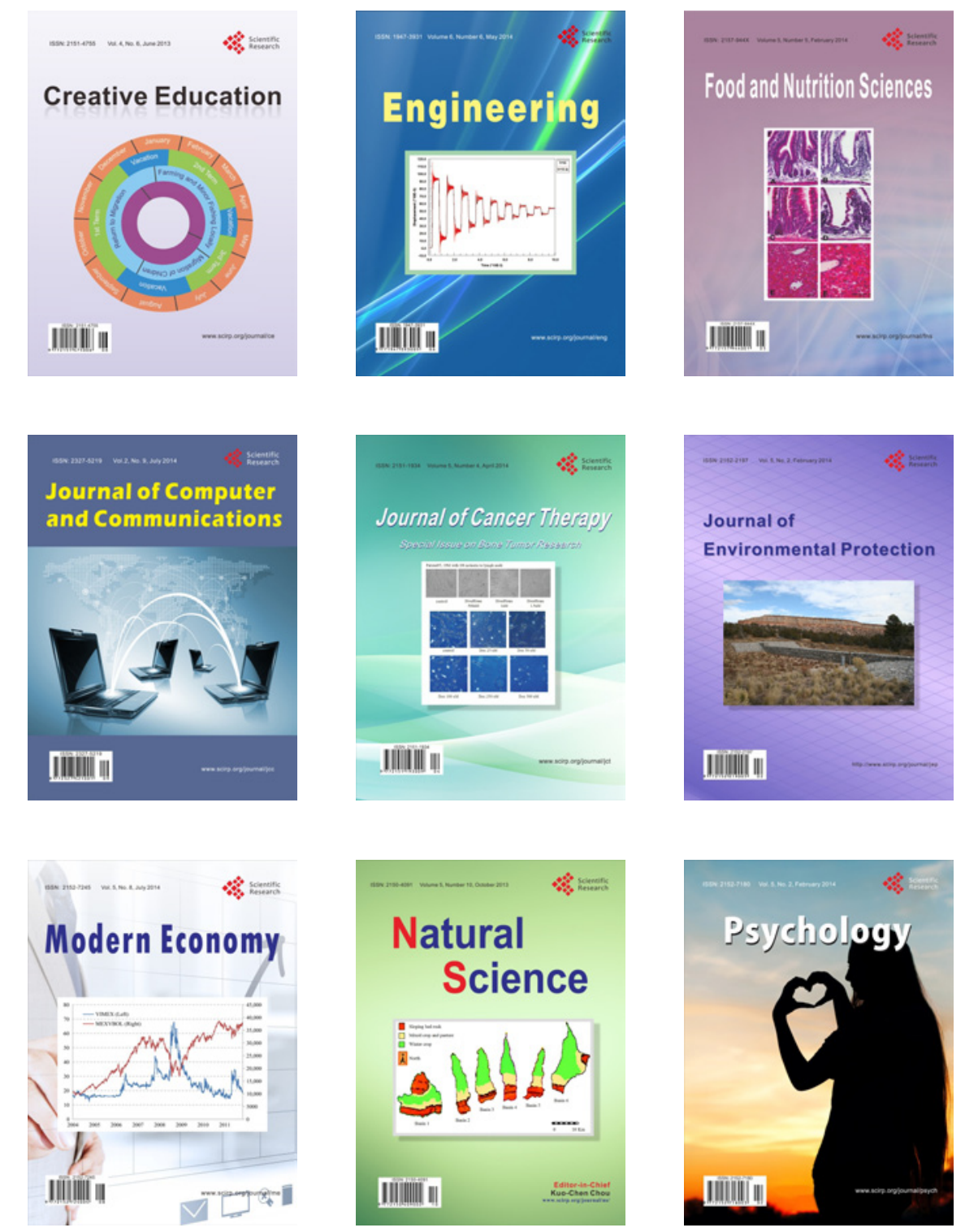